International

Medical Society

http://imedicalsociety.org
International Archives of Medicine

Section: Dental Medicine ISSN: 1755-7682
2016

Vol. 9 No. 392

doi: $10.3823 / 2263$

\section{Mucocele in Blandin-Nuhn Glands: \\ Case Report and Integrative Review}

\title{
Abstract
}

Introduction: Mucocele is a cystic benign lesion that does not present an epithelial lining, presenting saliva in its interior. It is linked to local traumas and obstruction of minor salivary glands.

Case Report: This article aims to present a rare case of mucocele in a Blandin-Nuhn gland highlighting the importance of the initial approach.

Discussion: Patient D.R.S. male gender, 14 years old, black, from Juazeiro do Norte - CE, attended to the dental clinic at UNILEÃO (Centro Universitário Leão Sampaio), with a complaint of "a lump in the mouth that dried out when bitten, with recurrences". Based on the clinical and histopathological findings a diagnosis of mucocele was considered. The medicine therapy performed was the administration of Ibuprofen, every 8 hours on a $300 \mathrm{mg}$ dose, during 3 days. Within 7 days of postoperative and medication, the repair of the tissues could be observed where the biopsy was performed and the patient presented a remission of the symptomatology and is under medical observation.

Conclusion: We conclude that the surgical removal of mucocele is the first choice treatment; the removal of the traumatic etiological agent is a conservative therapeutic alternative, in view of the clinical diagnosis of mucocele associated with traumas due to deleterious oral habits.

Italo Kennedy Silva Santos ${ }^{1}$, Jefferson David Melo de Matos ${ }^{1}$, Jéferson Martins Pereira Lucena Franco', Natã Cavalcante-Pereira1, Ivo Cavalcante Pita-Neto ${ }^{2}$, John Eversong Lucena de Vasconcelos ${ }^{3}$

1 School of Dentistry, Centro Universitário UNILEÃO, Juazeiro do Norte, Ceará.

2 Professor of Oral and Maxillofacial Surgery, Dentistry Department, Centro Universitário UNILEÃO, Juazeiro do Norte, Ceará.

3 Professor of Oral Implantology, Dentistry Department, Centro Caririense de Pós-Graduação CECAP, Juazeiro do Norte, Ceará.

\section{Contact information:}

John Eversong Lucena de Vasconcelos.

Address: Rua Sulino Duda, 113, Triangulo. Juazeiro do Norte, CE. CEP 63041-185

Tel: +55 (88) 3512-1590/+55 (88) 9.8802$4651 /+55$ (88) 9.9712-3250

Đjohnelvasconcelos@yahoo.com.br

\section{Keywords}

Mucocele; Oral Pathology; Salivary Glands. 


\section{Introduction}

Mucocele is a benign cystic lesion that is linked to minor salivary glands, and it is classified in two subtypes: Extravasation and retention. The phenomenon of extravasation and consequently the accumulation of liquid in between tissues is the most common. It commonly presents a bluish colour, liquid in the interior of its cavity, smooth surface and it is painless. However, it can have variations according to the degree of deepness of implantation, once its colour is similar to adjacent structures [1].

It is characterized as a pathology with predilection for young individuals, as it comprises the period in life that is most susceptible to traumas. The prevalence of this lesion is mainly in the inferior lip, which is explained by the location and disposition of the minor salivary glands [2].

Mucoceles involve minor salivary glands and their duct systems. In the histopathological examinations, a cavity well delimited is visualized, surrounded by a granulation tissue. It presents free mucin in its interior, plasma cells, lymphocytes and leukocytes. The involvement of the Blandin-Nuhn glands are less frequent in the population as they are disposed amongst the muscles in the ventral and anterior part of the tongue and it consequently is a region that have a greater protection and it is less susceptible to physical and mechanical traumas. It is classified as uncommon. Lesions in these glands present themselves in the same proportion as benign and Malignant, once mucoceles are the most prevalent benign lesions [3].

The knowledge of dentists about the anatomical and functional disposition of these glands is greatly important, so that normal and pathological elements can be distinguished. The complete removal of the injured glandular tissues is a challenge to dentists. Thus, well detailed clinical exams, knowledge about lesions that reach those regions and its distinct characteristics and the confirmation of histopathological examinations provides a greater efficacy in the removal of the lesions [4].
This article aims to present a rare case of mucocele in a Blandin-Nuhn gland with the importance of an initial approach, proceeded with a literature review, describing the most important aspects and the main controversies.

\section{Methods}

A bibliographic research was performed in the databases PUBMED (www.pubmed.gov) and SCIELO (www.scielo.org), which collected works that were published from 1992 to 2016. Literature review studies and case reports were included, which were reported in humans and as it follows, studies that did not approach mucocele in Blandin-Nuhn glands were excluded. Through the bibliographic research, 18 articles were selected, in which 12 were extracted from PUBMED and 6 from Scientific Electronic Library Online (Scielo), (Figure 1). All data were extracted and tabulated (Figure $\mathbf{2}$ and $\mathbf{3}$ ).

The following specific medical subject titles and keywords were used: (minor salivary glands (MeSH Terms) or Accessory salivary glands (MeSH Terms), Mucocele (Title/Abstract) or retention cyst of the

Figure 1: Scheme of the work search in the databases.

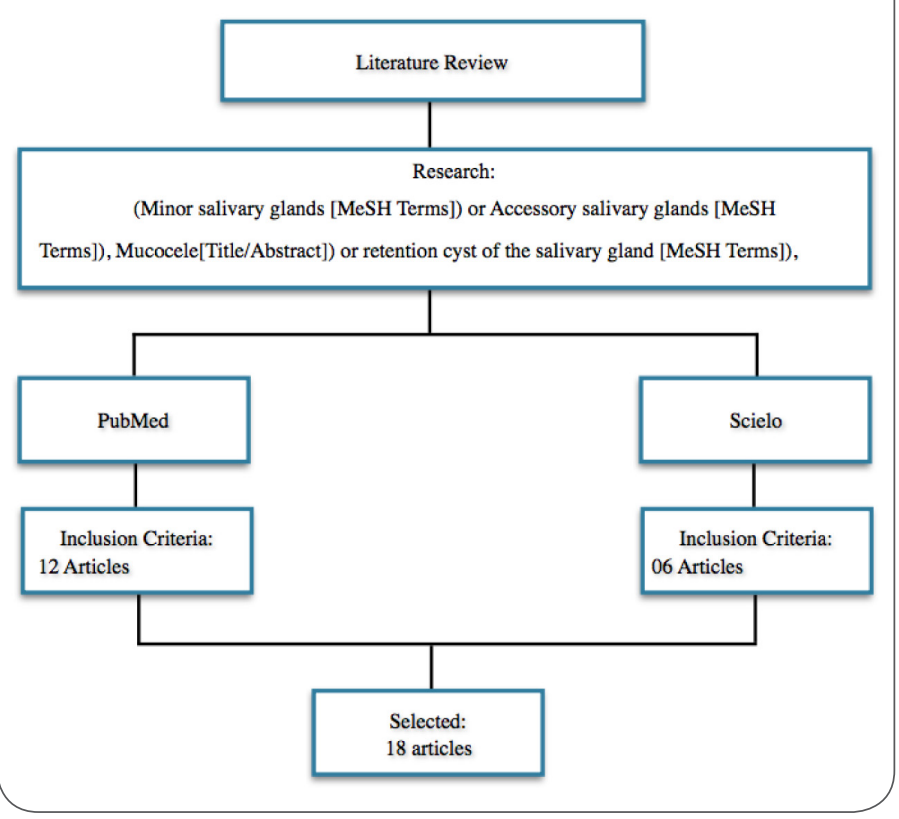


salivary gland (MeSH Terms), Oral Pathology (MeSH Terms).

Figure 2: Quantity of articles regarding years of publication.

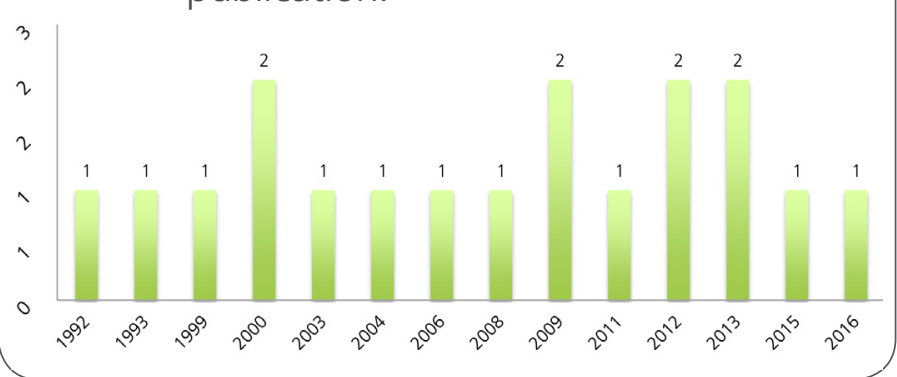

Figure 3: Cumulative graph of articles regarding years of publication.

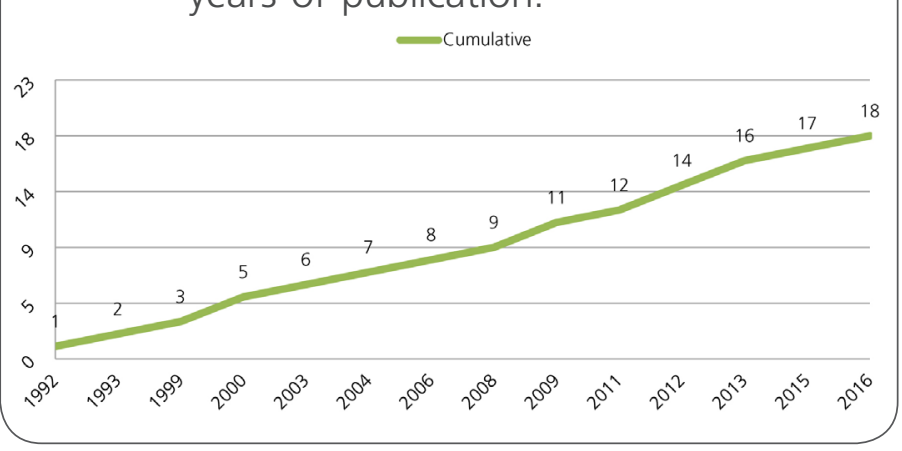

\section{Results}

Through the revision, all the works presented the approach of mucoceles in minor salivary glands of the anterior part of the tongue as being an uncommon pathology. The researchers performed the surgical excision in all of the cases, because it was explained as a high recurrence pathology. With that said, the resection of the affected glands would be greater. However, they did not highlight the use of electric scalpels during the surgical procedures in order to have a better haemostasis during the transoperative period (Table 1).

\section{Case Report}

Patient male gender, 14 years old, feoderm, from Juazeiro do Norte - CE, was transferred to the dental clinic of Centro Universitario Doutor Leão
Table 1. Results presented by the authors approach.

\begin{tabular}{|c|c|c|c|c|}
\hline Author & year & $\begin{array}{l}\text { Type of } \\
\text { study }\end{array}$ & $\begin{array}{l}\text { Number } \\
\text { of cases }\end{array}$ & Treatment \\
\hline $\begin{array}{l}\text { Ochiai; } \\
\text { Nakayama }\end{array}$ & $\begin{array}{c}2015 \\
{[13]}\end{array}$ & $\begin{array}{l}\text { Case } \\
\text { report }\end{array}$ & 1 & $\begin{array}{l}\text { Surgical } \\
\text { excision }\end{array}$ \\
\hline Martinez & $\begin{array}{c}2014 \\
{[8]}\end{array}$ & Analytical & 1 & $\begin{array}{l}\text { Surgical } \\
\text { excision }\end{array}$ \\
\hline Lajoto & $\begin{array}{c}2013 \\
{[5]}\end{array}$ & $\begin{array}{l}\text { Literature } \\
\text { review }\end{array}$ & - & $\begin{array}{l}\text { Surgical } \\
\text { excision }\end{array}$ \\
\hline Leon; Pardo & $\begin{array}{c}2013 \\
{[6]}\end{array}$ & $\begin{array}{l}\text { Case } \\
\text { Report }\end{array}$ & 1 & $\begin{array}{l}\text { Surgical } \\
\text { excision }\end{array}$ \\
\hline Matamala & $\begin{array}{c}2012 \\
{[9]}\end{array}$ & $\begin{array}{l}\text { Case } \\
\text { report }\end{array}$ & 26 & $\begin{array}{l}\text { Surgical } \\
\text { excision }\end{array}$ \\
\hline Joshi & $\begin{array}{c}2012 \\
{[4]}\end{array}$ & $\begin{array}{l}\text { Case } \\
\text { report }\end{array}$ & 1 & $\begin{array}{l}\text { Surgical } \\
\text { excision }\end{array}$ \\
\hline $\begin{array}{l}\text { Lypka; } \\
\text { Hammoudeh }\end{array}$ & $\begin{array}{c}2011 \\
{[10]}\end{array}$ & $\begin{array}{l}\text { Case } \\
\text { report }\end{array}$ & 1 & $\begin{array}{l}\text { Surgical } \\
\text { excision }\end{array}$ \\
\hline Nascimento & $\begin{array}{c}2009 \\
{[12]}\end{array}$ & $\begin{array}{l}\text { Case } \\
\text { report }\end{array}$ & 2 & $\begin{array}{l}\text { Surgical } \\
\text { excision }\end{array}$ \\
\hline Moraes & $\begin{array}{c}2009 \\
{[11]}\end{array}$ & Analytical & 42 & $\begin{array}{l}\text { Surgical } \\
\text { excision }\end{array}$ \\
\hline $\begin{array}{l}\text { Rai; Hegde; } \\
\text { Shetty }\end{array}$ & $\begin{array}{c}2008 \\
{[15]}\end{array}$ & $\begin{array}{l}\text { Case } \\
\text { report }\end{array}$ & 1 & $\begin{array}{l}\text { Surgical } \\
\text { excision }\end{array}$ \\
\hline Guimarães & $\begin{array}{c}2006 \\
{[1]}\end{array}$ & $\begin{array}{l}\text { Case } \\
\text { report }\end{array}$ & 1 & $\begin{array}{l}\text { Surgical } \\
\text { excision }\end{array}$ \\
\hline Mariano & 2004 & $\begin{array}{l}\text { Case } \\
\text { report }\end{array}$ & 1 & $\begin{array}{l}\text { Surgical } \\
\text { excision }\end{array}$ \\
\hline Jinbu & $\begin{array}{c}2003 \\
{[3]}\end{array}$ & $\begin{array}{l}\text { Case } \\
\text { report }\end{array}$ & 5 & $\begin{array}{l}\text { Surgical } \\
\text { excision }\end{array}$ \\
\hline Pérez; Jiménez. & $\begin{array}{c}2002 \\
{[14]}\end{array}$ & $\begin{array}{l}\text { Case } \\
\text { report }\end{array}$ & 5 & $\begin{array}{l}\text { Surgical } \\
\text { excision }\end{array}$ \\
\hline Riva A & $\begin{array}{c}2000 \\
{[16]}\end{array}$ & Analytical & 312 & $\begin{array}{l}\text { Surgical } \\
\text { excision }\end{array}$ \\
\hline Sugerman & $\begin{array}{c}2000 \\
{[18]}\end{array}$ & $\begin{array}{l}\text { Case } \\
\text { report }\end{array}$ & 5 & $\begin{array}{l}\text { Surgical } \\
\text { excision }\end{array}$ \\
\hline Riva A & $\begin{array}{c}1999 \\
{[17]}\end{array}$ & Analytical & 312 & $\begin{array}{l}\text { Surgical } \\
\text { excision }\end{array}$ \\
\hline Ishikawa & $\begin{array}{c}1993 \\
{[2]}\end{array}$ & $\begin{array}{l}\text { Case } \\
\text { report }\end{array}$ & 1 & $\begin{array}{l}\text { Surgical } \\
\text { excision }\end{array}$ \\
\hline Mandel; Kaynar. & $\begin{array}{c}1992 \\
{[7]}\end{array}$ & $\begin{array}{l}\text { Case } \\
\text { report }\end{array}$ & 1 & $\begin{array}{l}\text { Surgical } \\
\text { excision }\end{array}$ \\
\hline
\end{tabular}

Not reported by the authors 
Sampaio (UNILEÃO). The patient presented as the chief complaint "a lump in the mouth that dried out when bitten, with recurrences". As for the intraoral examination, a swelling of the mucosa in the ventral part of the tongue, which presented to have a dome-shaped lesion, soft to palpation, smooth surface, painless and colour varying from a tissue normal pink to bluish. The adjacent mucosa did not present signs of trauma and the evolution of the lesion was presented by the mechanisms of compression and decompression. In view of the literary findings, the suggested clinical diagnosis was mucocele in Blandin-Nunh glands. An infiltrative anaesthesia was performed around the lesion with $2 \%$ lidocaine. Posteriorly, an incision with an electrical scalpel was made in the area of the lesion, in order to have a control of haemostasis. Because, the ventral area of the tongue is a region that receives vascularization from the lingual vein and artery and innervation from the lingual nerve.

Figure 4: Clinical aspect of the lesion in the ventral region of the tongue.

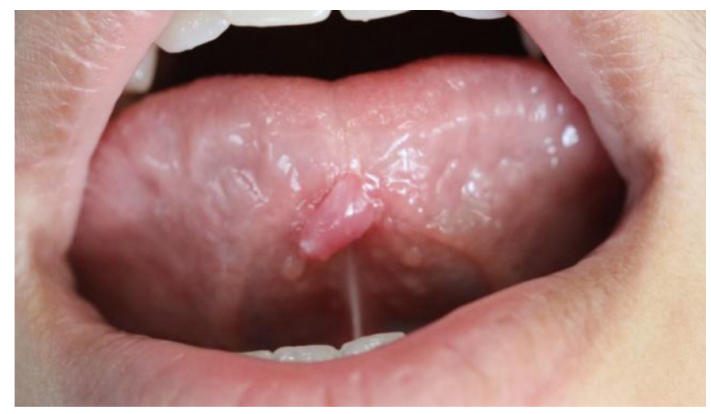

Figure 5: Aspect of the lesion with inoculation of threads in the tongue.

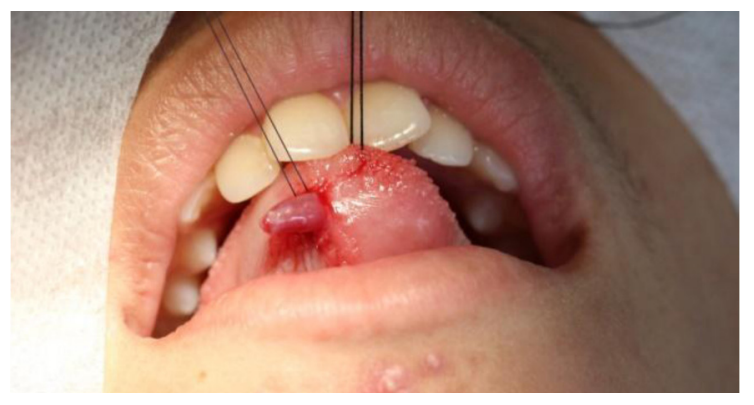

So, the electrocoagulation provides a favourable haemostasis of these vessels and a better view of the operative field. The surface of the cut lesion was regular and had liquid in its interior, similar to saliva with a greater degree of viscosity. Posteriorly, the lesion was placed in a $10 \%$ formalin solution and sent to the laboratory for histopathological examination. According to the macroscopic and microscopic analysis, the lesion presented $1.0 \mathrm{~cm}$, well delimited, surrounded by a granulation tissue and it had mucin in its interior. The granular adjacent tissue had inflammatory cells, so the clinical diagnosis was confirmed as mucocele in anterior glands of the tongue. The medicine therapy performed was the administration of Ibuprofen in a $300 \mathrm{mg}$ dose, every 8 hours during 3 days. Seven days after the operative procedure, the same was examined. A repair was observed in the area where the biopsy was performed and symptomatology was not reported. The patient was followed up

Figure 6: Incision of the lesion by heat..

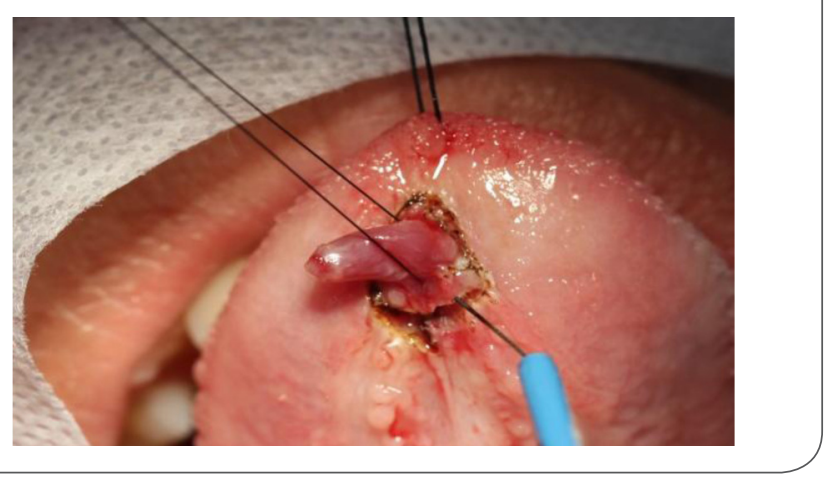

Figure 7: Aspect of the region after surgical removal of the pathologic tissue.

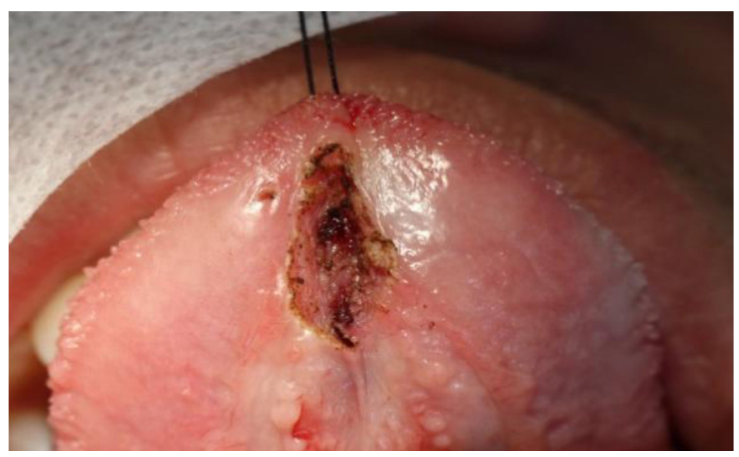


and re-evaluated 4 months after the surgery and did not present relapses of the lesion. (Figure 4 to 9 )

Figure 8: Aspect of the region after biopsy.



Figure 9: Biopsied pathologic fragment.

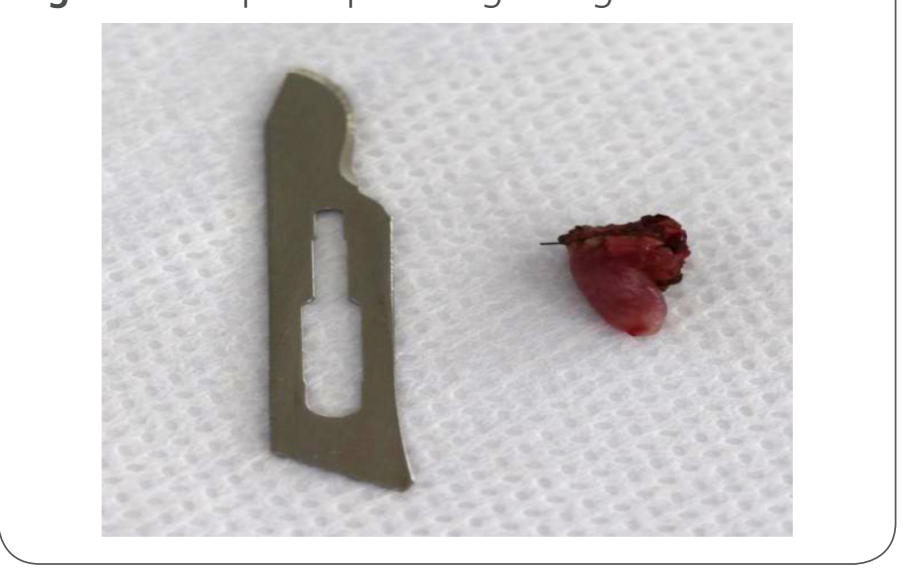

\section{Discussion}

Blandin-Nunh glands or anterior glands of the tongue present themselves in tube shapes and they are classified as mixed glands. However, there is a greater disposition of mucous cells. They are found lodged amongst the muscles in the ventral part of the tongue, with ducts that come out beside the lingual frenulum, presenting a content of filamentous bodies [5].

Research suggest that the casual factors most probable that explains the rising of mucoceles, are traumatic lesions, once they tear or obstruct the glands' ducts. During this process, there is an accumulation of saliva between the tissues and possibly it will be increasing according to the quantity of saliva produced [6].

Minor salivary glands are disposed through almost all the oral cavity, discharging at the buccal mucosa, palate and upper and lower lips. The same are composed in fewer numbers of seromucous or mixed cells, except the salivary glands that are disposed deeply in the posterior part of the tongue [6].

Mucoceles are lesions caused by mechanical or physical traumas that obstruct or tear the minor salivary glands. The subtype of extravasation of the lesion highlights a better perception in the histopathological examinations, compared to the phenomenon of obstruction [6, 7].

The use of thin needles for the obtaining of mucus in the interior of the lesion can be performed. Therefore, those professionals who have doubt in the oral clinical examination, can use this technique to make the diagnosis clear by presenting the content that is in the interior of lesions and differ from other pathologies [7].

The knowledge about macroscopic and microscopic characteristics is greatly important. The lack of knowledge on microscopic characteristics of tissues can suggest an erroneous diagnosis. Myxoglobulosis and papillary synovial-like metaplasia are rare conditions of Blandin-Nuhn glands mucoceles that can suggest mucocele neoplasms of salivary glands. [8]

Rioseco et al., 2012, advocate the performance of an incisional biopsy and transferring the patients to minimize the possibilities of erroneous diagnosis, once they do not agree that the clinical diagnosis itself is enough to diagnose Blandin-Nuhn glands mucoceles [9].

Moraes et al., 2009, report that the low prevalence of mucoceles in Blandin-Nuhn glands is due to a lack of diagnosis, erroneous diagnosis and mainly because mucoceles in these glands present thin walls and suffer rupture easily. For these reasons they cannot be considered rare lesions [10]. 
Lesions that affect the same location and develop the same characteristics as mucoceles in the anterior glands can occur in the interior on Blandin-Nuhn glands, such as minor salivary glands intraductal papillomas. It is suggested that these tumour cells emerge from the interior of the ducts [11].

The appearance of other lesions in the anterior region of the tongue is taken as differential diagnoses from clinical and histopathological characteristics. Thereby, the knowledge regarding pathologies and their diagnoses is indispensable. In cases of malignant neoplasms in these regions, one should transfer the patient to specific therapies [12].

When mucoceles are large and highly recurrent, marsupialisation is indicated to favour the regression of the size of the lesion and posteriorly perform a resection of the glands that suffered phenomena of obstruction or extravasation of their ducts [13].

Because they have high relapse rates, a complementary therapy to the surgical excision is the injection of silicone. It means to effectively delimitate the gland tissues that can be injured, once silicon delimitates the cells that suffered lesions during the pathogenic period, thus, avoiding to leave affected gland tissues, should they be obstructed or with extravasation [12, 13, 14].

Sugerman; Savage and Young, 2000, suggest the complete excision of lesions, covering deep areas of the musculature of the ventral tongue. During the transoperative, Blandin-Nuhn glands that are disposed amongst the ventral musculature of the tongue, routinely are not completely removed. Thereby, many glands remain in the location and it consequently causes a relapse of the lesion. Therefore, a preoperative anatomic approach may diminish the possibility of posterior surgeries [15].

Anterior salivary glands of the tongue are about 8 millimetres long and 2,5 millimetres deep. Anamnesis is very important to search for previous traumas and if the lesion relapses along the time or even deleterious habits in order to efficiently diagnose the lesions and posteriorly perform a biopsy and have a histopathological confirmation [16].

In view of all the above considerations, it was opted to perform a direct surgical removal through an excisional biopsy, once the literature points out that mucoceles in anterior glands of the tongue have a high rate of relapses. Thereby, the performance of marsupialisation was discarded [17].

The conventional surgical therapy was not chosen due to the high degree of vascularization in the anterior region, which would cause difficulties and possible complications in the haemostasis process. It was determined then to perform the surgery by electrocoagulation, which is an incision and at the same time coagulation occurs on the vessels that surround the lesion. However, professionals must be aware and have enough knowledge of the tongue anatomy, once it is a very irrigated area and still it receives innervation from branches of two pairs of cranial nerves [18].

\section{Conclusion}

Thereby, we observe that the surgical excision of mucoceles in Blandin-Nuhn glands is the first choice treatment, where the glands that had their ducts obstructed or with extravasation are removed. Another point is that deleterious habits are amongst the main etiological factors for this pathology. Also, a well detailed anamnesis and sound knowledge regarding this pathology makes the differential diagnoses easier when comparing mucoceles with other pathologies such as: Papillomas, fibroid, pyogenic granuloma and hemangioma.

\section{Conflicts of interest}

The authors declare that they have no conflicts of interest.

\section{Funding}

No funding was needed for this manuscript. 


\section{Ethical Approval}

No ethical approval was needed for this report.

\section{Consent}

The patient signed an informed consent to publish the case and all related figures.

\section{References}

1. Guimarães MS, Heblin J, Filho VAP, Santos LL, Vita TM, Costa CAS. Extravasation mucocele involving the ventral surface of the tongue (glands of Blandin-Nuhn). International Journal of Paediatric Dentistry 2006; 16: 435-439.

2. Ishikawa T, Imada S, juhin N. Intraductal papilloma of the anterior lingual salivary gland. Case report and immunohistochemical study. Int. J. Oral Maxillo Jkte. Surg.1993; 22: 116-117

3. Jinbu $Y$, Kumasa M, Itoh $H$, Matsumoto $K$, Wang J, Tochig TN. Mucocele of the glands of Blandin-Nuhn: Clinical and histopathologic analysis of 26 cases. Oral Surg Oral Med Oral Pathol Oral Radiol Endod. 2003;95: 467-70

4. Joshi SR, Pendyala GS, Choudhari S, and Kalburge J. Mucocele of the glands of blandi-nuhn in children: a clinical, histopathologic, and retrospective study. Nam J med Scj. 2012; 4: 379-83

5. Lajolo C, Favia GF, Fantasia J, CrespoM and Giuliani M. BlandinNuhn gland mucocele: presentation of a new case and review of the literature. Ann Stomatol. 2013;4:24

6. Leon NG, Pardo GM. Mucocele of glands od blandin nuhn: a case report. Colomb. Med. 2013; 44:1

7. Mandel L, Kaynar A. Mucocele of the gland of Blandin - Nuhn. N Y State Dent J. 1992; $58: 40-41$.

8. Martínez A, Arcila G, Carmona Z. Resección quirúrugica de mucocele utilizando relleno siliconado. Salud Barranquila. 2014; 30: 3

9. Matamala MAS., González MP, Rossel GD, Nieme CS. Lesiones intraorales de glandulas salivales menores. Revista Chilena de cirurgia. 2012. 64; 4: 335-340

10. Michael Lypka, M.D., D.M.D. Jeffrey Hammoudeh, M.D. Tongue Mucocele. The New England Journal of Medicinen engl $j$ med. 2011; 28: 365;

11. Moraes PC, Bönecker $M$, Furuse $C$, Thomaz LA,Teixeira RG and Araújo VC. Mucocele of the gland of Blandin-Nuhn: histological and clinical findings. Clin Oral Invest. 2009;13:351-353

12. Nascimento JS, Azevedo RS, Barros EMV, Takahama Junior A. Oral mucoceles: analysis of histopathological features of 42 cases. Rev Odontol Bras Central 2014; 23:162-165
13. Ochia A, Nakayama N. Congenital mucocele of the gland of Blandin-nuhn. Oxf med case reports. 2015; 12:374-5

14. Pérez $C$, Jiménez $C$. Mucoceles con localizaciones insuales: Report de casos. Acta odontologica venezolana. 2002;2: 40

15. Rai AJ, Hegde AM, Shetty YR. Management of Blandi-Nuhn mucocele: a case report. Clin Pediatr Dent. 2008; 32;147-9

16. Riva A, Puxeddu R, Uras L, Loy F, Serreli S and Testa Riva F. A high resolution sem study of human minor salivar glands. European Journal of Morphology. 2000; 38: 219-226.

17. Riva A, Lofferdo F, Puxeddu R, Testa Riva F. A scanning and transmission electron microscope study of the human minor salivary glands. Arch Oral Biol 1999;44:S27-31.

18. Sugerman PB, Savage NW and Young WG. Mucocele of the anterior lingual salivary glands (glands of Blandin and Nuhn): Report of 5 cases. Oral Surgery oral medicine oral pathology. 2000; 90: 478-82.

\section{Publish in International Archives of Medicine}

International Archives of Medicine is an open access journal publishing articles encompassing all aspects of medical science and clinical practice. IAM is considered a megajournal with independent sections on all areas of medicine. IAM is a really international journal with authors and board members from all around the world. The journal is widely indexed and classified Q2 in category Medicine. 